\title{
Lactobezoar and cows' milk protein intolerance
}

\author{
J N LEMOH AND JEAN WATT \\ St George's Hospital, and the Hospital for Sick Children, London
}

SUMMARY A baby girl of an atopic family who developed eczema, asthma, and cows' milk protein intolerance was found to have a gastric lactobezoar at age $9 \frac{1}{2}$ months. She responded well to the removal of the bezoar and to the appropriate dietary treatment.

The three known varieties of bezoars are trichobezoar, phytobezoar, and lactobezoar-trichobezoar probably being the most common. Lactobezoar is rare and was first reported in $1959 ;{ }^{1}$ since then 11 more cases have been described. To our knowledge the association of cows' milk protein intolerance and lactobezoar has not been reported.

\section{Case report}

Our patient was the third child of unrelated parents and was born normally at term weighing $3.6 \mathrm{~kg}$; both siblings have asthma which is also present in the father's family. She was exclusively breast fed for 6 weeks during which time she thrived and had no gastrointestinal symptoms, but she developed eczema. At 6 weeks a modified cows' milk formula (SMA) together with cereals was substituted for breast milk and, although the feeds were correctly made up and she fed well, this change was accompanied by vomiting and weight loss which persisted. At 4 months a diagnosis of cows' milk protein intolerance was considered and a soya-based milk (Velactin) was introduced; the vomiting promptly ceased and she again thrived. At 6 months vomiting recurred with weight loss, an exacerbation of the eczema, and episodes of wheezing. At 8 months an intestinal biopsy showed mild villous atrophy but other investigations were noncontributory. Cows' milk (unmodified) was reintroduced and gluten-containing foods stopped, but vomiting increased and her length and weight fell to well below the 3 rd centile.

At $9 \frac{1}{2}$ months, 6 weeks after reintroducing cows' milk, a barium meal showed mobile filling defects in the stomach (Figure). Other relevant investigations

Department of Paediatrics, Royal Hobart Hospital, Hobart, Tasmania

J N LEMOH

Department of Child Health, Institute of Child Health, London JEAN WATT, research assistant

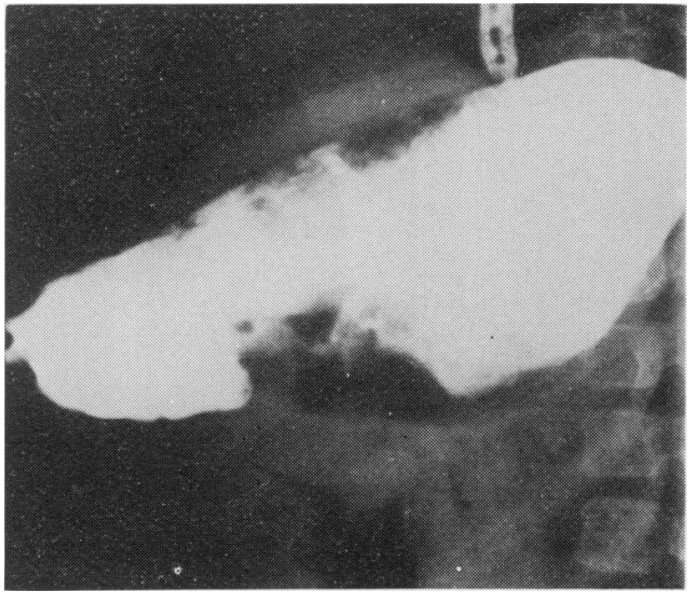

Figure Barium meal showing filling defects caused by lactobezoar.

were as follows: jejunal biopsy showed partial villous atrophy, and immunoperoxidase studies showed a pronounced increase in the lamina propria of IgA-containing plasma cells, and to a lesser extent IgM- and IgG-cells; eosinophil counts were repeatedly high, varying between 2000 and 3000 $\times 10^{9} / 1$; serum IgE levels were very high at 240 $\mathrm{IU} / \mathrm{ml}$ (normal 1-60), and gel diffusion tests for milk precipitins were positive; repeatedly low neutrophil yeast opsonisation indices of $1 \cdot 72,1 \cdot 40,1 \cdot 62$ were found (normal 2.5). Gastroscopy showed the stomach to be full of lactobezoar and milk curds. The lactobezoar was broken into small fragments and some of these were removed by suction. The gastric mucosa was macroscopically and microscopically normal. A cows' milk protein-free diet was reintroduced using a casein hydrolysate milk (Nutramigen); the vomiting resolved and she began to thrive. A barium meal was repeated 4 weeks after the gastroscopy and was normal. At 21 months intestinal 
biopsy was normal, cows' milk was reintroduced uneventfully, and a repeat biopsy 4 months later was also normal. She has remained well except for occasional episodes of wheezing, and at 25 months both her height and weight are on the 10th centile.

\section{Discussion}

The family history of asthma, the occurrence of eczema and asthma in the patient, the eosinophilia, high serum concentrations of IgE, positive milk precipitins, biopsy abnormalities, and the temporal relationship between the presence or absence of cows' milk in the diet and symptoms all support the diagnosis of cows' milk protein intolerance. The recurrence of symptoms at 6 months while on an apparently cows' milk-free diet (Velactin) remains unexplained. As the infant was having various cereals it is possible that the diet was not completely free of cows' milk protein, or alternatively, she may have developed an intolerance to soy protein; soy protein intolerance is a well established entity, ${ }^{2}$ and combined soy and cows' milk protein intolerance has been reported. ${ }^{3}$ Another possibility is that the lactobezoar had already formed and the vomiting was secondary to gastric outlet obstruction. The finding of repeatedly low opsonisation indices may have been incidental since this defect is present in 1 in 20 of the general population, ${ }^{4-5}$ but it is interesting to note that Turner et al. ${ }^{6}$ found that $27 \%$ of atopic patients had defective opsonisation.

In all but 3 of the previously reported patients with lactobezoar inappropriately concentrated feeds had been given to the children, and this was considered to be a factor in the formation of the lactobezoars. All 3 correctly fed infants were aged less than 3 months and presented with vomiting, ${ }^{7-8}$ as was the case in our patient. Our patient differed however, in that she was also intolerant of cows' milk protein, but whether this relationship was causal or incidental is uncertain. The mechanism of lactobezoar formation is largely speculative. Majd and Lopresti ${ }^{9}$ suggested that lactobezoars formed as a result of diarrhoea or vomiting, or both, compensatory reduction in gastric juice secretions, and subsequent impaction of curds to form the bezoar; this then produced mechanical obstruction and further vomiting. Such a mechanism would, of course, be more likely to operate in infants fed cows' milk because of its relatively higher content of casein and calcium, particularly if the feeds were concentrated. It is tempting to speculate that lactobezoar may be more common than realised in infants with cows' milk protein intolerance in whom vomiting is prolonged, particularly if associated with episodes of dehydration.

We thank Dr S J R Macoun for referring the patient, Dr J Dow for the radiology, Mr J A S Dickson for removing the bezoar, and Dr J T Harries and Professor June K Lloyd for permission to publish.

\section{References}

1 Wolf R S, Bruce J. Gastrostomy for lactobezoar in a newborn infant. J Pediatr 1959; 54: 811-2.

2 Ament M E, Rubin C E. Soy protein-another cause of the flat intestinal lesion. Gastroenterology 1972; 62: 227-34.

3 Whitington P F, Gibson R. Soy protein intolerance: four patients with concomitant cows' milk intolerance. Pediatrics 1977; 59: 730-2.

4 Soothill J F, Harvey B A M. Defective opsonisation. A common immunity deficiency. Arch Dis Child 1976; 51: 91-9.

5 Yamamura M, Da Silva G, Valdimarsson H. A new semi-quantitative radiometric opsonin assay. Selective measurement of opsonizing capacity of the alternative pathway. Immunology 1978; 34: 689-94.

6 Turner M W, Mowbray J F, Harvey B A M, Brostoff J, Wells R S, Soothill J F. Defective yeast opsonisation and C2 deficiency in atopic patients. Clin Exp Immunol 1978; 34: 253-9.

7 Cremin B J, Fisher R M, Stokes N J, Rabkin J. Four cases of lactobezoar in neonates. Pediatr Radiol 1974; 2 : 107-10.

8 Sullivan M A, Smith R T. Letter: Lactobezoars-a simple therapy. Am J Dis Child 1977; 131 : 813.

9 Majd M, Lopresti J M. Lactobezoar. AJR 1972; 116: 575-6.

Correspondence to Professor June Lloyd, St George's Hospital, Department of Child Health, Blackshaw Road, London SW17 OQT.

Received 15 February 1979 